\title{
The mobility of nitrification inhibitors under simulated ruminant urine deposition and rainfall: a comparison between DCD and DMPP
}

\author{
Karina A. Marsden ${ }^{1}$ - Antonio J. Marín-Martínez ${ }^{2}$ - Antonio Vallejo ${ }^{3}$ • Paul W. Hill ${ }^{1}$. \\ Davey L. Jones ${ }^{1}$ - David R. Chadwick ${ }^{1}$
}

Received: 2 October 2015 /Revised: 14 January 2016 / Accepted: 22 January 2016 / Published online: 4 February 2016

(C) The Author(s) 2016. This article is published with open access at Springerlink.com

\begin{abstract}
Urine patches within pasture soils are hotspots for nitrogen $(\mathrm{N})$ cycling and losses, where nitrification inhibitors (NI) offer a means of reducing such losses. Within urine influenced soil, more research has been conducted for dicyandiamide (DCD) than 3,4-dimethylpyrazole phosphate (DMPP). Differences in the efficacy of these NI are often ascribed to a greater mobility of DCD, which may lead to spatial separation from $\mathrm{NH}_{4}^{+}$and nitrifying microorganisms. We tested the mobility of ${ }^{14} \mathrm{C}$-labelled DCD and DMPP relative to sheep urine-derived $\mathrm{NH}_{4}{ }^{+}$in soil columns of contrasting texture and organic matter content, following simulated rainfall. We also assessed factors influencing the vertical mobility of these NI in soils, including solubility, sorption/ desorption processes and microbial degradation and uptake. Following 40-mm rainfall, without the presence of sheep urine, the distribution of both NI were similar in the soil columns; however, there was a greater retention of DCD compared to DMPP in the top $1 \mathrm{~cm}$. Both NI appeared to co-locate well with urine-derived $\mathrm{NH}_{4}{ }^{+}$, and the presence of sheep urine altered the leaching profile of the NI (compared to rainfall application alone), but this effect was inhibitor and soil-type dependent. A greater sorption to the soil matrix was observed
\end{abstract}

Karina A. Marsden

k.marsden@bangor.ac.uk

1 School of Environment, Natural Resources and Geography, Bangor University, Bangor, Gwynedd LL57 2UW, UK

2 Department of Agrochemistry and Environment, Miguel Hernandez University, EPS-Orihuela, ctra. Beniel Km 3.2, 03312, Orihuela Alicante, Spain

3 ETSI Agronomos, Technical University of Madrid, Ciudad Universitaria, 28040 Madrid, Spain for DCD in comparison to DMPP in all three studied soils, and the presence of urine generally increased desorption processes. Of the NI applied to the soil columns, 18-66\% was taken up within $30 \mathrm{~min}$ by the microbial community. However, only small amounts $(<1 \%)$ were mineralized during this period. In conclusion, due to the greater adsorption of DCD as opposed to DMPP and similarity in the degree of co-location of both NI with urine $\mathrm{NH}_{4}{ }^{+}$, the results of this study suggest that differences in microbial uptake and degradation may be more important parameters for explaining differences in the efficacy of reducing nitrification. Further work is required to determine the comparative efficacy of both NI in reducing nitrification rates under field conditions in a range of soil types and environmental conditions.

Keywords Grazed grassland · Livestock ecosystems · Nitrogen use efficiency $\cdot$ Nutrient dynamics

\section{Introduction}

In pasture soils, high loadings of nitrogen $(\mathrm{N})$ are deposited within ruminant urine patches and these sites are particularly vulnerable to losses of $\mathrm{N}$ to the environment. Typically, $20 \%$ of deposited urinary $\mathrm{N}$ is leached as $\mathrm{NO}_{3}{ }^{-}, 13 \%$ is volatilised as $\mathrm{NH}_{3}$ and $2 \%$ is emitted as the greenhouse gas $\mathrm{N}_{2} \mathrm{O}$ (Selbie et al. 2015). While $\mathrm{N}_{2} \mathrm{O}$ constitutes a small agronomic loss in terms of magnitude of $\mathrm{N}$, having nearly 300 times the global warming potential of $\mathrm{CO}_{2}$ (IPCC 2007), it accounts for $46 \%$ of agricultural greenhouse gas emissions (Smith et al. 2007). The agricultural sector will need to contribute to decreasing emissions (Misselbrook et al. 2014) in order to achieve targets ( $80 \%$ reduction from 1990 baseline levels by 2050) set by the $\mathrm{UK}$ and other governments. Reducing $\mathrm{N}$ loss via $\mathrm{NO}_{3}{ }^{-}$ leaching and improving $\mathrm{N}$ use efficiency would translate to a 
direct economic benefit for farmers, and reducing $\mathrm{N}_{2} \mathrm{O}$ emissions from grasslands could contribute to decreasing emissions from the livestock sector.

Nitrification inhibitors (NI) are a potential mitigation strategy which can reduce losses of $\mathrm{N}$ from urine patches deposited to grassland soils (Di and Cameron 2012; Ledgard et al. 2014; Luo et al. 2015). By delaying the conversion of $\mathrm{NH}_{4}{ }^{+}$to $\mathrm{NO}_{3}{ }^{-}$, the opportunity for plant acquisition, immobilisation, fixation and adsorption of $\mathrm{NH}_{4}{ }^{+}$is increased (Di and Cameron 2007). This can potentially reduce emissions of $\mathrm{N}_{2} \mathrm{O}$ from both nitrification and denitrification (Gilsanz et al., 2016), where nitrification has been shown to be the dominant $\mathrm{N}_{2} \mathrm{O}$ producing process in soils with a WFPS of 35-60\%, but at a higher WFPS (70 \%), denitrification becomes the dominant $\mathrm{N}_{2} \mathrm{O}$-producing process (Bateman and Baggs 2005). By the same processes, NI can also reduce the amount of $\mathrm{NO}_{3}{ }^{-}$available for leaching (Di and Cameron 2004).

Two of the most widely used NI are dicyandiamide (DCD) and dimethylpyrazole-phosphate (DMPP) (Liu et al. 2013). DCD blocks the electron transport chain in the cytochrome of ammonia monoxygenase (AMO), whereas DMPP binds indiscriminately to the membrane-bound AMO (Chaves et al. 2006; Fiencke and Bocke 2006; Benckiser et al. 2013), delaying the first and rate-limiting step of nitrification (the oxidation of $\mathrm{NH}_{4}^{+}$to $\mathrm{NO}_{2}^{-}$; Zerulla et al. 2001). In comparison to DCD, DMPP has been shown to be less phytotoxic and lower application rates are required (Wissemeier et al. 2001; Zerulla et al. 2001; Di and Cameron 2012). Both NI have demonstrable efficacy in reducing $\mathrm{N}$ losses from fertiliser applications (Weiske et al. 2001; Liu et al. 2013) and livestock slurry (Fangueiro et al. 2009; Pereira et al. 2010); however, DCD applications to urine patches have been more widely researched (e.g. Di and Cameron 2003; O'Callaghan et al. 2010; de Klein et al. 2011) in comparison to DMPP (e.g. Di and Cameron 2011; Di and Cameron 2012). Some authors have found a difference between the efficacy of DCD and DMPP, e.g. Weiske et al. (2001) found DMPP to be reduce $\mathrm{N}_{2} \mathrm{O}$ emissions from fertiliser by an average of $49 \%$, whereas DCD reduced emissions by an average of $26 \%$. Di and Cameron (2012), however, found that DCD and DMPP reduced $\mathrm{N}_{2} \mathrm{O}$ emissions by a similar amount from cattle urine (62 and $66 \%$ reduction, respectively). The efficacy of NI in reducing $\mathrm{N}_{2} \mathrm{O}$ emissions and $\mathrm{NO}_{3}{ }^{-}$leaching can vary widely. In a laboratory study of nine contrasting UK soils, the efficacy of DCD to inhibit $\mathrm{NH}_{4}{ }^{+}$oxidation, net $\mathrm{NO}_{3}{ }^{-}$production and emissions of $\mathrm{N}_{2} \mathrm{O}$ was lower in soils of high temperature, clay content and organic matter content (McGeough et al. 2016). Differences in efficacy have been attributed to a lower mobility of DMPP in comparison to DCD, due to a greater sorption of DMPP (Wissemeier et al. 2001; Zerulla et al. 2001; Di and Cameron 2012). Having a high mobility may lead to the spatial separation of $\mathrm{NI}$ from $\mathrm{NH}_{4}{ }^{+}$and nitrifying microorganisms (Ruser and Schulz 2015).
Physicochemical characteristics which can influence mobility within soil include solubility and sorption/desorption processes (Carrillo-González et al. 2006). The greater the solubility of a chemical in water, the greater the potential for vertical transport. The sorption/desorption of chemicals within the soil is mainly influenced by the organic matter content of soil, where charges associated with the chemical influences the types of bond established. DCD is a net neutrally charged molecule and binding takes place on the surface of organic matter, through hydrogen bonding of the $-\mathrm{NH}_{2}$ and $=\mathrm{NH}$ functional groups to negative carboxyl groups of organic matter (Zhang et al. 2004; Singh et al. 2008; Shepherd et al. 2012). Conversely, DMPP is positively charged and adsorption is thought to occur to the mineral fraction of soils, such as clays and silts (Barth et al. 2001, 2008). As chemicals are transported through soil, further biological transformations may influence the quantity of substance available for vertical movement, e.g. microbial uptake and mineralization. As DMPP is a heterocyclic compound, it is not readily degradable, resulting in a slower degradation rates in soil in comparison to DCD (Weiske et al. 2001; Chaves et al. 2006). In the specific conditions of urine influenced soils, the high concentration of $\mathrm{NH}_{4}^{+}$, $\mathrm{K}^{+}$and other cations may saturate cation exchange sites leading to further movement of NI down the soil profile.

The objective of this study was to obtain information on how the combination of NI characteristics and soil conditions can affect the mobility and co-location of $\mathrm{NH}_{4}{ }^{+}$and $\mathrm{NI}$ in soils, with ruminant urine as the source of $\mathrm{NH}_{4}{ }^{+}$. We investigated physicochemical (solubility and sorption/desorption) and biological (microbial uptake and degradation) factors influencing the vertical mobility of DCD and DMPP, in soil columns of contrasting texture and organic matter following a 40-mm rainfall event, with and without the presence of sheep urine. We hypothesised that (1) DCD would move further down the soil profile than DMPP following simulated rainfall, due to a greater sorption of DMPP, (2) a greater co-location would be observed for DMPP with urine $\mathrm{NH}_{4}{ }^{+}$, due to the lower mobility of DMPP, (3) the presence of sheep urine would increase vertical movement and desorption of both NI, due to saturation of soil exchange sites by ions within sheep urine and (4) a greater microbial uptake and mineralization would occur for DCD in comparison to DMPP, due to a greater bioavailability of DCD in comparison to DMPP.

\section{Materials and methods}

\section{Soil and sheep urine analysis}

Three soil types were selected for experimentation, on the basis of contrasting texture and organic matter content: a sandy loam textured Eutric Cambisol $\left(53^{\circ} 24^{\prime} \mathrm{N}, 4^{\circ} 02^{\prime} \mathrm{W}\right)$, a sandy clay loam textured Eutric Cambisol (53 $14^{\circ} \mathrm{N}, 4^{\circ} 01^{\prime}$ 
W) and a high organic matter containing Sapric Histosol (52 $52^{\prime} \mathrm{N}, 0^{\circ} 47^{\prime} \mathrm{W}$ ). Both Eutric Cambisol samples were collected from beneath moderately sheep grazed and fertilised pasture, and the Sapric Histosol was collected from a eutrophic lowland peat used in intensive arable agriculture. The soil types used in this study had not been previously exposed to either DCD or DMPP. A summary of soil properties is presented in Table 1.

Soil was sampled in triplicate $(0-10 \mathrm{~cm}$ depth), sieved $(<2 \mathrm{~mm})$ in order to reduce sample heterogeneity and stored at $4{ }^{\circ} \mathrm{C}$ until required. Soil moisture content was determined by weight difference after oven drying $\left(105^{\circ} \mathrm{C}\right)$, and organic matter was determined on dry soil by loss-on-ignition in a muffle furnace $\left(450^{\circ} \mathrm{C}\right.$; Ball 1964). Soil C:N ratio was determined on oven-dried ground soil samples using a TruSpec ${ }^{\circledR}$ Analyzer (Leco Corp., St. Joseph, MI). The cation exchange capacity (CEC) of soils was determined using an unbuffered salt extraction method of Schofield (1949). Soil pH and electrical conductivity (EC) were measured using standard electrodes (1:2.5 (w/v) soil-to-distilled water). Soluble $\mathrm{C}$ and $\mathrm{N}$ were determined in 1:5 soil-to- $0.5 \mathrm{M} \mathrm{K}_{2} \mathrm{SO}_{4}$ extracts using a Multi N/C 2100S Analyzer (AnalytikJena, Jena, Germany), within $24 \mathrm{~h}$ of sample collection, according to Jones and Willett (2006). Microbial C and $\mathrm{N}$ were determined using the chloroform fumigation-extraction method of Voroney et al. (2008) $\left(K_{\mathrm{EC}}=0.35\right.$ and $\left.K_{\mathrm{EN}}=0.5\right)$. Total available nitrate $\left(\mathrm{NO}_{3}{ }^{-}\right)$, ammonium $\left(\mathrm{NH}_{4}{ }^{+}\right)$and phosphate $(\mathrm{P})$ were determined within $0.5 \mathrm{M} \mathrm{K}_{2} \mathrm{SO}_{4}$ extracts via the colorimetric procedures of Miranda et al. (2001), Mulvaney (1996) and Murphy and Riley (1962), respectively. Cations $\left(\mathrm{Na}^{+}, \mathrm{K}^{+}\right.$ and $\left.\mathrm{Ca}^{2+}\right)$ were determined within 1:5 $(w / v)$ soil-to-1 $\mathrm{M}$ $\mathrm{NH}_{4} \mathrm{Cl}$ extracts using a Sherwood Model 410 Flame Photometer (Sherwood Scientific Ltd, Cambridge, UK).

Sheep urine was collected from Welsh mountain ewes fed a diet of $80 \%$ Lolium perenne $\mathrm{L}$. and $20 \%$ Trifolium repens L., where several urine samples from a single sheep were pooled. The urine was frozen (unacidified) before use to avoid losses of N. The sheep urine had a $\mathrm{pH}$ of 8.99 and an EC of $22 \mathrm{mS} \mathrm{cm}{ }^{-1}$; the urine contained a total of $2.27 \mathrm{~g} \mathrm{~N}^{-1}$, $3.00 \mathrm{~g}$ organic $\mathrm{Cl}^{-1}, 1.71 \mathrm{~g}$ urea $\mathrm{N} \mathrm{l}^{-1}, 44.9 \mathrm{mg} \mathrm{NH}_{4}^{+}-\mathrm{N} \mathrm{l}^{-1}$, $0.44 \mathrm{mg} \mathrm{NO}_{3}{ }^{-}-\mathrm{N} \mathrm{l}^{-1}, 0.92 \mathrm{mg} \mathrm{Pl}^{-1}, 7.16 \mathrm{~g} \mathrm{~K} \mathrm{l}^{-1}, 1.11 \mathrm{~g} \mathrm{Na}^{-1}$ and $73.3 \mathrm{mg} \mathrm{Ca}^{-1}$. Properties were measured directly on the urine via the methods described above, and urea was measured using the method of Orsonneau et al. (1992).

\section{Comparative mobility of ${ }^{14} \mathrm{C}-\mathrm{DCD}$ and ${ }^{14} \mathrm{C}$-DMPP under simulated rainfall}

To compare the mobility of $[\mathrm{U}]{ }^{14} \mathrm{C}$-DCD and $5-{ }^{14} \mathrm{C}$-DMPP (American Radiolabeled Chemicals, St Louis, MO, USA) in
Table 1 Properties of soils $(0$ $10 \mathrm{~cm}$ ) used to fill the soil columns

\begin{tabular}{|c|c|c|c|}
\hline Soil property & Sandy loam & Sandy clay loam & Sapric Histosol \\
\hline Texture: sand (\%) & $80.0 \pm 2.52 \mathrm{~b}$ & $49.0 \pm 2.00 \mathrm{a}$ & ND \\
\hline Silt (\%) & $11.7 \pm 2.19 \mathrm{a}$ & $31.3 \pm 0.88 \mathrm{~b}$ & ND \\
\hline Clay $(\%)$ & $8.33 \pm 0.67 \mathrm{a}$ & $19.7 \pm 1.20 \mathrm{~b}$ & ND \\
\hline Organic matter $(\%)$ & $5.40 \pm 0.29 \mathrm{a}$ & $5.10 \pm 0.44 \mathrm{a}$ & $77.6 \pm 0.36 b$ \\
\hline Gravimetric moisture content $(\%)$ & $14.2 \pm 0.12 \mathrm{a}$ & $19.5 \pm 0.33 b$ & $61.2 \pm 0.10 \mathrm{c}$ \\
\hline Cation exchange capacity (meq $100 \mathrm{~g}^{-1}$ ) & $14.0 \pm 0.29 \mathrm{a}$ & $14.8 \pm 0.68 \mathrm{a}$ & $80.8 \pm 0.80 \mathrm{~b}$ \\
\hline $\mathrm{pH}$ & $6.64 \pm 0.15 \mathrm{a}$ & $6.42 \pm 0.04 \mathrm{a}$ & $6.37 \pm 0.06 \mathrm{a}$ \\
\hline Electrical conductivity $\left(\mu \mathrm{S} \mathrm{cm}^{-1}\right)$ & $51.1 \pm 13.5 \mathrm{a}$ & $67.8 \pm 7.34 \mathrm{ab}$ & $107 \pm 11.8 \mathrm{~b}$ \\
\hline Total C $\left(\mathrm{g} \mathrm{kg}^{-1}\right)$ & $24.1 \pm 2.50 \mathrm{a}$ & $19.1 \pm 0.76 \mathrm{a}$ & $392 \pm 1.33 \mathrm{~b}$ \\
\hline Total $\mathrm{N}\left(\mathrm{g} \mathrm{kg}^{-1}\right)$ & $3.29 \pm 0.14 \mathrm{a}$ & $3.12 \pm 0.13 \mathrm{a}$ & $26.6 \pm 0.09 \mathrm{~b}$ \\
\hline Dissolved organic $\mathrm{C}\left(\mathrm{mg} \mathrm{C} \mathrm{kg}^{-1}\right)$ & $52.7 \pm 2.57 \mathrm{a}$ & $64.7 \pm 13.4 \mathrm{a}$ & $959 \pm 79.1 \mathrm{~b}$ \\
\hline Total dissolved $\mathrm{N}\left(\mathrm{mg} \mathrm{N} \mathrm{kg}^{-1}\right)$ & $7.51 \pm 0.78 \mathrm{a}$ & $9.92 \pm 0.66 \mathrm{a}$ & $71.4 \pm 6.98 b$ \\
\hline Microbial C $\left(\mathrm{g} \mathrm{kg}^{-1}\right)$ & $0.35 \pm 0.01 \mathrm{a}$ & $0.38 \pm 0.04 \mathrm{a}$ & $4.41 \pm 0.20 \mathrm{~b}$ \\
\hline Microbial N $\left(\mathrm{mg} \mathrm{kg}^{-1}\right)$ & $27.2 \pm 0.79 \mathrm{a}$ & $26.1 \pm 1.33 \mathrm{a}$ & $777 \pm 42.3 \mathrm{~b}$ \\
\hline Extractable $\mathrm{NH}_{4}^{+}\left(\mathrm{mg} \mathrm{N} \mathrm{kg}^{-1}\right)$ & $0.20 \pm 0.01 \mathrm{a}$ & $0.24 \pm 0.03 \mathrm{a}$ & $6.50 \pm 0.46 \mathrm{~b}$ \\
\hline Extractable $\mathrm{NO}_{3}{ }^{-}\left(\mathrm{mg} \mathrm{N} \mathrm{kg}^{-1}\right)$ & $0.61 \pm 0.14 \mathrm{a}$ & $0.89 \pm 0.12 \mathrm{a}$ & $29.3 \pm 2.73 b$ \\
\hline Extractable $\mathrm{P}\left(\mathrm{mg} \mathrm{kg}^{-1}\right)$ & $0.32 \pm 0.004 \mathrm{a}$ & $0.08 \pm 0.04 \mathrm{a}$ & $26.1 \pm 3.59 \mathrm{~b}$ \\
\hline Exchangeable $\mathrm{K}$ (meq kg ${ }^{-1}$ ) & $2.39 \pm 0.43 \mathrm{a}$ & $1.61 \pm 0.31 \mathrm{a}$ & $8.95 \pm 3.79 \mathrm{a}$ \\
\hline Exchangeable $\mathrm{Na}\left(\mathrm{meq} \mathrm{kg}{ }^{-1}\right)$ & $0.77 \pm 0.08 \mathrm{a}$ & $1.37 \pm 0.08 \mathrm{a}$ & $5.17 \pm 0.51 \mathrm{~b}$ \\
\hline Exchangeable $\mathrm{Ca}\left(\mathrm{meq} \mathrm{kg}{ }^{-1}\right)$ & $51.8 \pm 1.51 \mathrm{a}$ & $53.3 \pm 2.12 \mathrm{a}$ & $617 \pm 17.4 b$ \\
\hline
\end{tabular}

Values represent means $\pm \mathrm{SEM}, n=3$; letters indicate significant differences between the soils; results are reported on a dry soil weight basis

$N D$ stands for not determined 
contrasting soils under a simulated rainfall event, polypropylene tubes ( $n=3 ; 15 \mathrm{~cm}$ depth; $0.8 \mathrm{~cm}$ diameter) were repacked with sieved, field moist soil (soil sampled at $0-10 \mathrm{~cm}$ depth) to approximate field bulk density values $(9,8$ and $5 \mathrm{~g}$ for the sandy loam, sandy clay loam and Sapric Histosol). This resulted in bulk densities of 1.0, 0.9 and $0.4 \mathrm{~g} \mathrm{~cm}^{-3}$ and porosities of $0.60,0.67$ and 0.71 in the sandy loam, sandy clay loam and Sapric Histosol soil columns, respectively (particle density was assumed to be $2.65 \mathrm{~g} \mathrm{~cm}^{-3}$ in the mineral soils and $1.4 \mathrm{~g} \mathrm{~cm}^{-3}$ in the organic soils; Rowell 1994). The bottom of the tubes contained nylon mesh, to allow for drainage of leachate and to prevent any loss of soil. Nevertheless, no leachate was present following the rainfall simulations. Field relevant application rates of either ${ }^{14} \mathrm{C}-\mathrm{DCD}\left(1 \mathrm{~g} \mathrm{l}^{-1} ; 50 \mu \mathrm{l}\right.$; ca. $1 \mathrm{kBq})$ or ${ }^{14} \mathrm{C}$-DMPP $\left(0.1 \mathrm{~g} \mathrm{l}^{-1} ; 50 \mu \mathrm{l} ; \mathrm{ca} .1 \mathrm{kBq}\right)$ were applied to the top of the column, and a $40-\mathrm{mm}$ rainfall event was simulated by adding $2 \mathrm{ml}$ of distilled water dropwise to the soil columns, ca. 5 min after the application of the NI. This rainfall event was chosen to simulate UK storm conditions which promote rapid water movement down the soil profile. It should also be noted that these leaching rates also approximate rates of water movement down preferential flow pathways in the soil profile under lower rainfall events. Preliminary studies indicated that the wetting front generally reached but did not exceed the soil column length $(15 \mathrm{~cm})$.

The soil columns were incubated for $0.5 \mathrm{~h}$, at laboratory temperature, after which, the tubes were cut into the following depth fractions with a scalpel: $0-1,1-2,2-3,3-5,5-7,7-9$, $9-12$ and $12-15 \mathrm{~cm}$. The entire cut sections (including tube, to extract soil adhered to inner edge) were extracted with $0.5 \mathrm{M}$ $\mathrm{K}_{2} \mathrm{SO}_{4}(1: 5 w / v ; 0.5 \mathrm{~h} ; 150 \mathrm{rpm})$. An aliquot $(1.5 \mathrm{ml})$ of the soil solution was centrifuged $(14,000 \mathrm{~g} ; 5 \mathrm{~min})$ and the resulting supernatant was mixed with HiSafe 3 scintillant (PerkinElmer, Llantrisant, UK) and the activity measured using a Wallac 1404 Liquid Scintillation Counter (Wallac EG\&G, Milton Keynes, UK).

\section{Effect of ruminant urine on NI mobility and co-location of NI with urine ammonium}

To determine if the presence of urine influences the vertical movement of DCD or DMPP, soil columns $(n=3)$ were prepared and processed as above. A sheep urine deposition event was simulated ca. 2 min following application of the ${ }^{14} \mathrm{C}$ DCD or ${ }^{14} \mathrm{C}$-DMPP and preceding the simulated rainfall event, by applying $250 \mu \mathrm{l}$ of sheep urine to the top of the soil column. The vertical distribution of the NI was compared to soil columns incubated without urine.

The $\mathrm{NH}_{4}{ }^{+}$concentration of the $0.5 \mathrm{M} \mathrm{K}_{2} \mathrm{SO}_{4}$ extracts of each depth fraction was also determined on the urine-treated soil columns, via the method described previously, to determine the co-location of ${ }^{14} \mathrm{C}$-DCD and ${ }^{14} \mathrm{C}$-DMPP with urinederived $\mathrm{NH}_{4}^{+}$.

\section{Solubility of DCD and DMPP in water}

To determine the water solubility of DCD and DMPP, the OECD (1995) flask method was used. Briefly, $5 \mathrm{~g}$ of NI was added to $10 \mathrm{ml}$ of water $(n=3)$ and incubated at $30^{\circ} \mathrm{C}$ on a rotary shaker for $24 \mathrm{~h}$. One replicate was then removed and incubated at $20{ }^{\circ} \mathrm{C}$ for $24 \mathrm{~h}$ with occasional shaking, before centrifuging at $10,000 \mathrm{~g}$. Samples were syringe filtered $(0.2 \mu \mathrm{m})$ and analysed for total dissolved $\mathrm{C}$, as described above, and the amount of NI dissolved in the water calculated. One of the remaining replicates was incubated for another $24 \mathrm{~h}$ at $30^{\circ} \mathrm{C}$, and the final replicate was incubated for an additional $48 \mathrm{~h}$, before incubation at $20^{\circ} \mathrm{C}$ for a further $24 \mathrm{~h}$ and preparation of samples for analysis of dissolved C. This was conducted to ensure additional time had no effect on the amount of NI dissolved.

\section{Sorption and desorption}

Sorption isotherms were determined for ${ }^{14} \mathrm{C}$-DCD and ${ }^{14} \mathrm{C}$ DMPP in the three contrasting soils in the presence and absence of sheep urine. Briefly, ${ }^{14} \mathrm{C}$-DCD or ${ }^{14} \mathrm{C}$-DMPP was applied $(50 \mu \mathrm{l}$; ca. $1 \mathrm{kBq})$ to $0.5 \mathrm{~g}(n=3)$ of field moist soil, following which $2.5 \mathrm{ml}$ of either $0.01 \mathrm{M} \mathrm{CaCl}_{2}$ or sheep urine was added to the soils. A total of eight concentrations of ${ }^{14} \mathrm{C}$ DCD and ${ }^{14} \mathrm{C}$-DMPP were used, ranging from 0.08 $10 \mathrm{mg} \mathrm{NI} 1^{-1}$. The soil suspensions were shaken for $0.5 \mathrm{~h}$ at $150 \mathrm{rpm}$ on a rotary shaker, subsequently an aliquot $(1.5 \mathrm{ml})$ was centrifuged $(10,000 g ; 5 \mathrm{~min})$ and the ${ }^{14} \mathrm{C}$ activity in the supernatant determined by liquid scintillation counting, as above. Sorption of $\mathrm{NH}_{4}^{+}$was also assessed as described above, using eight concentrations ranging from $2.3-300 \mathrm{mg}$ $\mathrm{NH}_{4}{ }^{+}-\mathrm{N}^{-1}$, in $0.01 \mathrm{M} \mathrm{CaCl}_{2}$. The $\mathrm{NH}_{4}^{+}$concentration in the supernatant was determined as above. The partition coefficient $\left(K_{\mathrm{d}}\right)$ for the NI (with and without the presence of urine) and $\mathrm{NH}_{4}{ }^{+}$within soil was determined via Eq. 1, where $C_{\text {ads }}$ $\left(\mu \mathrm{mol} \mathrm{kg}{ }^{-1}\right)$ is the concentration adsorbed to the soil solid phase at equilibrium and $C_{\mathrm{sol}}\left(\mu \mathrm{mol} \mathrm{l}^{-1}\right)$ is the adsorbate concentration remaining in solution at equilibrium.

$K_{\mathrm{d}}=C_{\mathrm{ads}} / C_{\mathrm{sol}}$

Desorption, with and without the presence of sheep urine, was determined by adding either ${ }^{14} \mathrm{C}$-DCD $(25 \mu \mathrm{l}$; ca. $0.5 \mathrm{kBq})$ or ${ }^{14} \mathrm{C}$-DMPP $(25 \mu \mathrm{l}$; ca. $0.5 \mathrm{kBq})$ at two concentrations ( 1 and $\left.10 \mathrm{mg}^{-1}\right)$ to $0.2 \mathrm{~g}$ of soil $(n=3)$. Four successive washes of the soil were conducted by adding either $1 \mathrm{ml}$ of $0.01 \mathrm{M} \mathrm{CaCl}_{2}$ or sheep urine and by conducting a final wash with $0.5 \mathrm{M} \mathrm{K}_{2} \mathrm{SO}_{4}$. Samples were shaken for $0.5 \mathrm{~h}$ at $150 \mathrm{rpm}$ on a rotary shaker between the additions of fresh wash solution. At the end of each wash period, the samples were centrifuged $(10,000 \mathrm{~g} ; 5 \mathrm{~min})$ and the supernatant removed prior to adding fresh $0.01 \mathrm{M} \mathrm{CaCl}_{2}$ or sheep urine. The activity in 
the supernatant was determined as described previously, where the activity residing in the entrained solution trapped within the soil matrix was accounted for. After the final wash, soils were dried $\left(105^{\circ} \mathrm{C} ; 24 \mathrm{~h}\right)$ and ground before combustion in an OX400 biological oxidizer (RJ Harvey, Hillsdale, NJ, USA), where evolved ${ }^{14} \mathrm{CO}_{2}$ was captured in Oxysolve C-400 (Zinsser analytic, Frankfurt, Germany) to quantify ${ }^{14} \mathrm{C}$ remaining bound to soils following washes.

\section{Substrate mineralization and microbial uptake}

Mineralization of ${ }^{14} \mathrm{C}$-DCD and ${ }^{14} \mathrm{C}$-DMPP in the three soils was determined to quantify the degradation of the NI during the course of the incubation. $0.3 \mathrm{ml}$ of ${ }^{14} \mathrm{C}-\mathrm{DCD}$ or ${ }^{14} \mathrm{C}$-DMPP (ca. $0.5 \mathrm{kBq} \mathrm{ml}^{-1} ; 0.1$ and $1 \mathrm{~g} \mathrm{l}^{-1}$ ) were added to $1 \mathrm{~cm}^{3}$ of soil $(n=3)$, contained in $10 \mathrm{~cm}^{3}$ glass vessels. Evolved ${ }^{14} \mathrm{CO}_{2}$ was captured by flowing (ca. $100 \mathrm{ml} \mathrm{min}^{-1}$ ) moist air over the soil surface, with the outflow passing through two consecutive $0.1 \mathrm{M} \mathrm{NaOH}$ traps (capture efficiency $>95 \%$; Hill et al. 2007). Traps were changed after $0.05,0.12,0.25,0.5,1,2,4$ and $8 \mathrm{~h}$, and the activity in the solution determined by liquid scintillation counting as above.

To enable calculation of the ${ }^{14} \mathrm{C}$-NI pool taken up by soil microbes, ${ }^{14} \mathrm{C}$-DCD or ${ }^{14} \mathrm{C}$-DMPP $(0.3 \mathrm{ml}$; ca. $0.5 \mathrm{kBq}$; 0.1 and $\left.1 \mathrm{~g} \mathrm{l}^{-1}\right)$ was pipetted evenly onto the soil surface $(1 \mathrm{~g}$; $n=3)$ and extractions using ice-cold $0.5 \mathrm{M} \mathrm{K}_{2} \mathrm{SO}_{4}(1: 5 w / v)$ were conducted at $0.05,0.12,0.25,0.5$ and $1 \mathrm{~h}$ following addition of the substrate. The soils were shaken $(150 \mathrm{rpm}$; $0.5 \mathrm{~h})$ and subsequently centrifuged $(10,000 \mathrm{~g}, 10 \mathrm{~min})$. The ${ }^{14} \mathrm{C}$ in the resulting supernatant was determined via liquid scintillation counting as described above. Uptake of the substrate by soil microbes was calculated by deducting the $0.5 \mathrm{M}$ $\mathrm{K}_{2} \mathrm{SO}_{4}$ extractable pool from the starting ${ }^{14} \mathrm{C}$ pool. This is assuming the extraction procedure removed all exchangeable ${ }^{14} \mathrm{C}$-NI and the remainder was taken up into the microbial biomass.

\section{Statistical analysis}

To compare the vertical mobility of ${ }^{14} \mathrm{C}-\mathrm{DCD}$ and ${ }^{14} \mathrm{C}$-DMPP under rainfall, to determine how urine influences the vertical mobility of the NI and to compare the co-location of the NI with that of urine- $\mathrm{NH}_{4}{ }^{+}$, a one-way ANOVA with Tukey's post hoc test was used to compare each section depth, following testing for normality (Ryan-Joiner test) and homogeneity of variance (Levene's test). The same analysis was conducted on the slope of the linear sorption isotherms, following $\log$ transformation of data. A one-way ANOVA was also conducted for desorption after the fourth wash in either urine or $\mathrm{CaCl}_{2}$, for mineralization at the 8-h time point and microbial uptake after $1 \mathrm{~h}$. All statistical analyses were performed in Minitab 17.1.0 (Minitab Inc., State College, PA).

\section{Results}

\section{Comparative vertical mobility of NI following simulated rainfall}

The distribution of extractable DCD- $-{ }^{14} \mathrm{C}$ and DMPP $-{ }^{14} \mathrm{C}$ following simulated rainfall was generally similar within each soil type (Fig. 1). However, a greater retention of ${ }^{14} \mathrm{C}-\mathrm{DCD}$ was observed in comparison to ${ }^{14} \mathrm{C}$-DMPP in the top $0-1-\mathrm{cm}$ depth fraction of the sandy loam (Fig. 1a) and sandy clay loam columns (Fig. 1b). The total amount of DCD- ${ }^{14} \mathrm{C}$ extracted from the columns with $0.5 \mathrm{M} \mathrm{K}_{2} \mathrm{SO}_{4}$ after $0.5 \mathrm{~h}$ was 66.6 $\pm 1.29,63.9 \pm 0.65$ and $38.8 \pm 0.53 \%$ of that applied to the sandy loam, sandy clay loam and the Sapric Histosol, respectively. In comparison, the percentage of DMPP- ${ }^{14} \mathrm{C}$ extracted from the columns was $79.4 \pm 2.14,72.5 \pm 1.42$ and 39.1 $\pm 1.39 \%$ of that applied to the sandy loam, sandy clay loam and Sapric Histosol, respectively.

The presence of sheep urine reduced $(p<0.01)$ the quantity of extractable DCD $-{ }^{14} \mathrm{C}$ and DMPP $-{ }^{14} \mathrm{C}$ in the top $1 \mathrm{~cm}$ of the sandy loam columns (Fig. 1a, d), increased $(p<0.01)$ the amount of extractable DCD- ${ }^{14} \mathrm{C}$ in the bottom $12-15$-cm depth fraction and had no effect $(p>0.05)$ on the extractable amount of DCD- ${ }^{14} \mathrm{C}$ and DMPP- $-{ }^{14} \mathrm{C}$ in each remaining depth fraction. The presence of sheep urine did not influence the extractable amount of DCD- ${ }^{14} \mathrm{C}$ or DMPP- $-{ }^{14} \mathrm{C}$ in any studied depth fraction of the sandy clay loam columns (Fig. 1b, e). The presence of urine had no effect $(p>0.05)$ on the amount of extractable DCD- ${ }^{14} \mathrm{C}$ in each depth fraction of the Sapric Histosol (Fig. 1c, f). However, it decreased $(p<0.001)$ the extractable amount of DMPP- $-{ }^{14} \mathrm{C}$ from the top $1 \mathrm{~cm}$ and increased $(p<0.001)$ the extractable amount in the $12-15-\mathrm{cm}$ depth fraction.

The percentage of applied DCD- $-{ }^{14} \mathrm{C}$ extracted from the soil columns with applied sheep urine plus rainfall was 79.6 $\pm 6.58,72.9 \pm 1.92$ and $43.6 \pm 0.73 \%$ of the added label applied to the sandy loam, the sandy clay loam and Sapric Histosol, respectively. The total amount of DMPP- ${ }^{14} \mathrm{C}$ extracted from soils under the same conditions was $79.4 \pm 0.77,71.5$ \pm 3.54 and $47.9 \pm 0.01 \%$ in the sandy loam, sandy clay loam and Sapric Histosol, respectively. In conclusion, urine increased the total amount of DCD extracted from the soils, but had no effect on DMPP.

\section{Co-location of NI with urine-derived ammonium}

In general, the distribution of both DCD- ${ }^{14} \mathrm{C}$ and DMPP- ${ }^{14} \mathrm{C}$ within the soil profile coincided well with the urine-derived $\mathrm{NH}_{4}^{+}$(Fig. 2). A greater $(p<0.001)$ percentage of total column extractable DCD- $-{ }^{14} \mathrm{C}$ in comparison to $\mathrm{NH}_{4}{ }^{+}$was found in the top $1 \mathrm{~cm}$ in all three soil types (Fig. 2a-c), indicating a retention of DCD at the soil surface. A greater $(p<0.001)$ percentage of total extractable $\mathrm{NH}_{4}{ }^{+}$in comparison to DMPP $-{ }^{14} \mathrm{C}$ was found in the $9-12-\mathrm{cm}$ depth fraction of the 


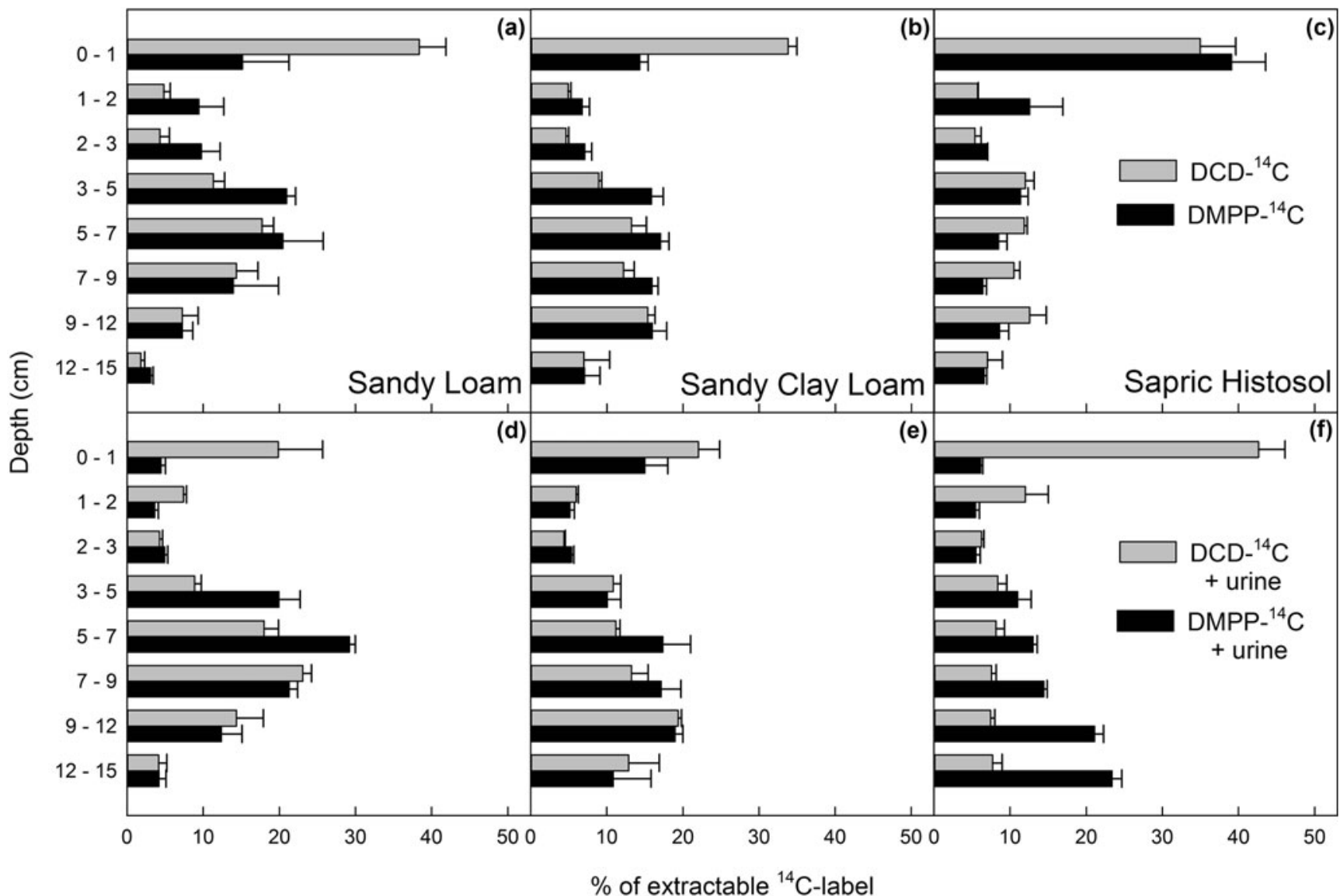

Fig. 1 The percentage of extractable DCD- ${ }^{14} \mathrm{C}$ or DMPP- ${ }^{14} \mathrm{C}$ at depth fractions of sandy loam (a, d), sandy clay loam $(\mathbf{b}, \mathbf{e})$ and Sapric Histosol (c, f) columns, following a simulated $40-\mathrm{mm}$ rainfall event $(\mathbf{a}-\mathbf{c})$ and a sheep urine deposition plus a 40-mm rainfall event (d-f). Soil type labels apply to each column and legends apply to each row of panels. Bars represent means $(n=3)$ and error bars represent SEM sandy loam columns (Fig. 2d). Greater $(p<0.001)$ amounts of total extractable $\mathrm{NH}_{4}{ }^{+}$in comparison to DCD- ${ }^{14} \mathrm{C}$ were also found in the 9-12-cm depth fraction of the sandy clay loam columns (Fig. 2e), indicating some dis-location of NI with $\mathrm{NH}_{4}{ }^{+}$at depth. No differences were observed at any depth fraction for DMPP- $-{ }^{14} \mathrm{C}$ and urine- $\mathrm{NH}_{4}{ }^{+}$in the sandy clay loam or the Sapric Histosol columns (Fig. 2e, f, respectively), indicating similar vertical distributions under conditions of mass flow.

\section{Solubility of DCD and DMPP in water}

The solubility of DMPP at $20{ }^{\circ} \mathrm{C}$ was significantly higher $(p<0.001)$ at $125 \pm 2.4 \mathrm{~g} \mathrm{l}^{-1}$ in comparison to that of DCD at $73.2 \pm 2.0 \mathrm{~g} \mathrm{l}^{-1}$. An increasing trend was not observed in the replicates maintained for 48 and $72 \mathrm{~h}$, indicating that saturation of the NI within the matrix had occurred after $24 \mathrm{~h}$.

\section{Sorption}

Sorption isotherms for DCD- ${ }^{14} \mathrm{C}$ (Fig. 3a, c, e), DMPP- ${ }^{14} \mathrm{C}$ (Fig. 3b, d, f) and $\mathrm{NH}_{4}^{+}$(Fig. 4) were linear, where all $R^{2}$ values were greater than 0.95 . The gradient of the linear sorption isotherms were steeper $(p<0.001)$ in the Sapric Histosol compared to the other soil types for both $\mathrm{DCD}-{ }^{14} \mathrm{C}$, DMPP $-{ }^{14} \mathrm{C}$ and $\mathrm{NH}_{4}{ }^{+}$indicating greater amounts of sorption in this soil type. In comparison to DMPP- ${ }^{14} \mathrm{C}$, greater sorption occurred for DCD- ${ }^{14} \mathrm{C}$ in the Sapric Histosol in both matrices (0.01 $\mathrm{M} \mathrm{CaCl}_{2}$ and urine). However, no differences were observed between DCD- ${ }^{14} \mathrm{C}$ and DMPP- ${ }^{14} \mathrm{C}$ sorption in the other two soil types $(p>0.05)$. In the Sapric Histosol, the gradient of the DMPP $-{ }^{14} \mathrm{C}$ sorption isotherm was steeper $(p<0.001)$ in the $0.01 \mathrm{M} \mathrm{CaCl}_{2}$ matrix as opposed to the urine matrix. The calculated soil-to-solution partition coefficients $\left(K_{\mathrm{d}}\right.$; Table 2$)$ followed the trend sandy loam $<$ sandy clay loam $<$ Sapric Histosol for DCD- $-{ }^{14} \mathrm{C}$, DMPP $-{ }^{14} \mathrm{C}$ and $\mathrm{NH}_{4}{ }^{+}$; for the NI, this trend was observed at both concentrations and within both matrices.

\section{Desorption}

Generally, the presence of urine increased total desorption (Fig. 5) of both DCD- ${ }^{14} \mathrm{C}$ and DMPP- ${ }^{14} \mathrm{C}$ numerically (although not statistically) at the fourth consecutive wash, in all 


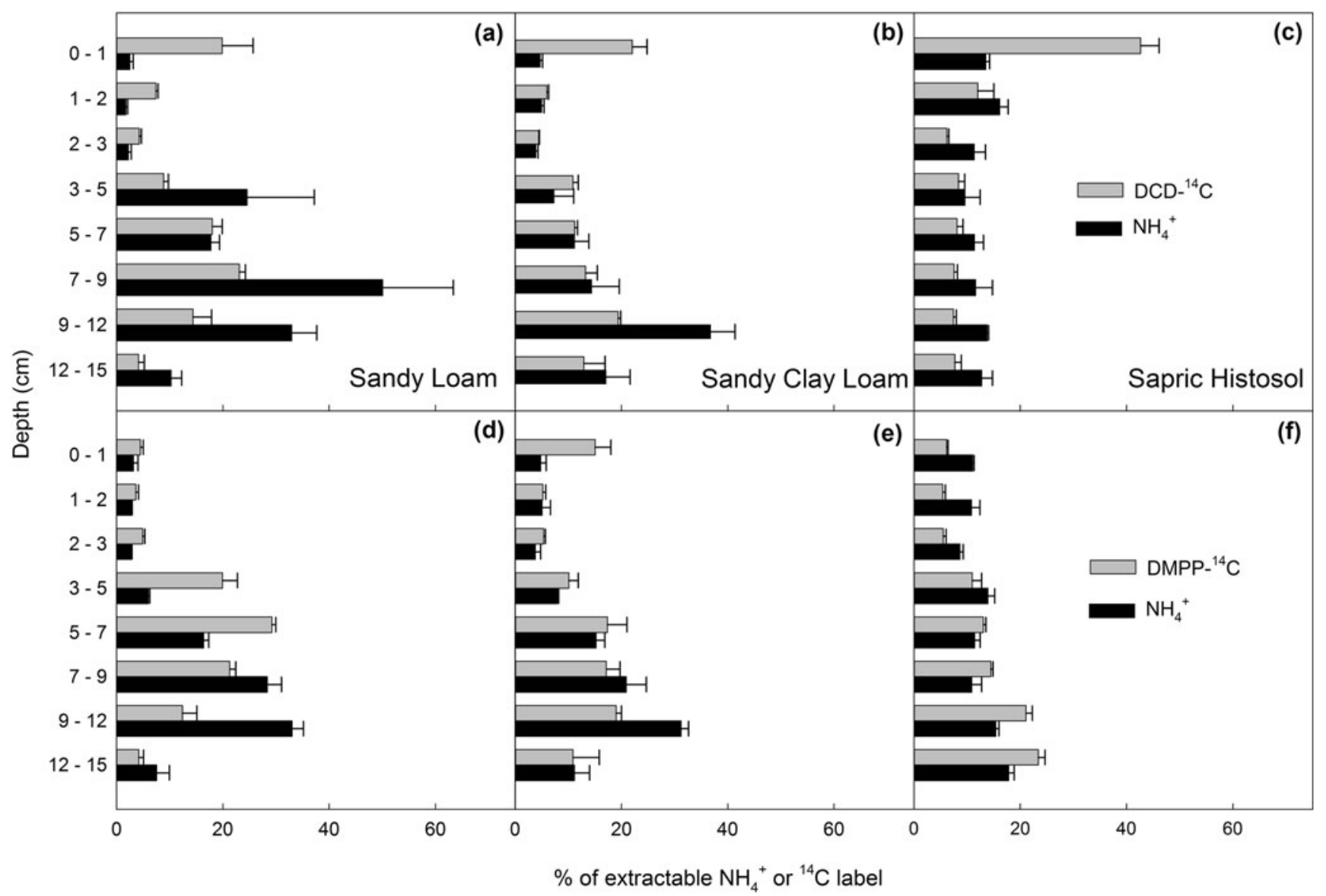

Fig. 2 The percentage of extractable DCD- ${ }^{14} \mathrm{C}(\mathbf{a}-\mathbf{c})$ or DMPP- $-{ }^{14} \mathrm{C}(\mathbf{d}-\mathbf{f})$ compared to $\mathrm{NH}_{4}^{+}$at differing soil depth fractions following a simulated urine deposition plus a 40-mm rainfall event applied to sandy loam (a, d), sandy clay loam (b, d) and Sapric Histosol (c, f) columns. Soil type labels apply to each column and legends apply to each row of panels. Bars represent means $(n=3)$ and error bars denote SEM soil types. The presence of urine increased desorption of DMPP- ${ }^{14} \mathrm{C}$ in the Sapric Histosol at $1 \mathrm{mg} \mathrm{l}^{-1}(p<0.001$; Fig. 5k) and $10 \mathrm{mg} \mathrm{l}^{-1}(p<0.05$; Fig. 51). Interestingly, the same trend was not observed for DCD- ${ }^{14} \mathrm{C}$ in the same soil type (Fig. 5i, j). Desorption of DCD $-{ }^{14} \mathrm{C}$ in the $\mathrm{CaCl}_{2}$ matrix was greater $(p<0.05)$ in the sandy loam soil (Fig. 5a, b) compared to the Sapric Histosol (Fig. 5i, j), but desorption was no greater $(p>0.05)$ in the sandy clay loam soil (Fig 5e, f). In the urine matrix, desorption of DCD- ${ }^{14} \mathrm{C}$ was lower $(p<0.01)$ in the Sapric Histosol (Fig. 5i, j) compared to the sandy loam (Fig. 5a, b) and sandy clay loam (Fig. 5e, f) textured Eutric Cambisol at both studied concentrations. For both studied concentrations of DMPP $-{ }^{14} \mathrm{C}$ in the $\mathrm{CaCl}_{2}$ matrix, desorption was lower $(p<0.01)$ in the Sapric Histosol (Fig. 5k, 1) in comparison to either the sandy loam (Fig. 5c, d) or the sandy clay loam (Fig. 5g, h) Eutric Cambisol. In the urine matrix, however, no differences in desorption of DMPP- ${ }^{14} \mathrm{C}$ was observed at either concentration between the soil types.

When comparing between the applied ${ }^{14} \mathrm{C}-\mathrm{NI}$ in the $\mathrm{CaCl}_{2}$ matrix, there was a greater desorption $(p<0.05)$ of DMPP- ${ }^{14} \mathrm{C}$ (Fig. 5e, f) in comparison to DCD- ${ }^{14} \mathrm{C}$ (Fig. $5 \mathrm{~g}, \mathrm{~h}$ ) in the sandy clay loam. The same trend was true for the urine matrix, except no differences were observed between $\mathrm{DCD}-{ }^{14} \mathrm{C}$ and DMPP- ${ }^{14} \mathrm{C}$ at $1 \mathrm{mg}$ compound $\mathrm{l}^{-1}$. In the urine matrix, greater $(p<0.001)$ amounts of DMPP- ${ }^{14} \mathrm{C}$ (Fig. $\left.5 \mathrm{k}, 1\right)$ desorbed in comparison to DCD- ${ }^{14} \mathrm{C}$ (Fig. 5i, j) in the Sapric Histosol, at both studied concentrations. The final wash conducted with $0.5 \mathrm{M} \mathrm{K}_{2} \mathrm{SO}_{4}$ typically only increased desorption by minor amounts (ranging from 1.4 to $6.0 \%$ ), indicating that the previous washes had removed the majority of the extractable $\mathrm{NI}-{ }^{14} \mathrm{C}$ from the soils. The mass balance for the total recovered DCD- ${ }^{14} \mathrm{C}$ and DMPP- $-{ }^{14} \mathrm{C}$ following biological oxidation was $101 \pm 0.63 \%$ and $101 \pm 0.95 \%$, respectively, for all soil types, applied concentrations and matrices.

\section{Mineralization}

The results of the mineralization assay confirmed that only minor degradation of the ${ }^{14} \mathrm{C}-\mathrm{NI}$ would have occurred under the conditions and duration $(0.5 \mathrm{~h})$ of the column study. Mineralization of ${ }^{14} \mathrm{C}-\mathrm{DCD}$ within all three soil types ranged from 0.10 to $0.35 \%$ of added ${ }^{14} \mathrm{C}$ label, over $0.5 \mathrm{~h}$. For ${ }^{14} \mathrm{C}$-DMPP, the amount degraded over the period of the column incubation was even lower, ranging 


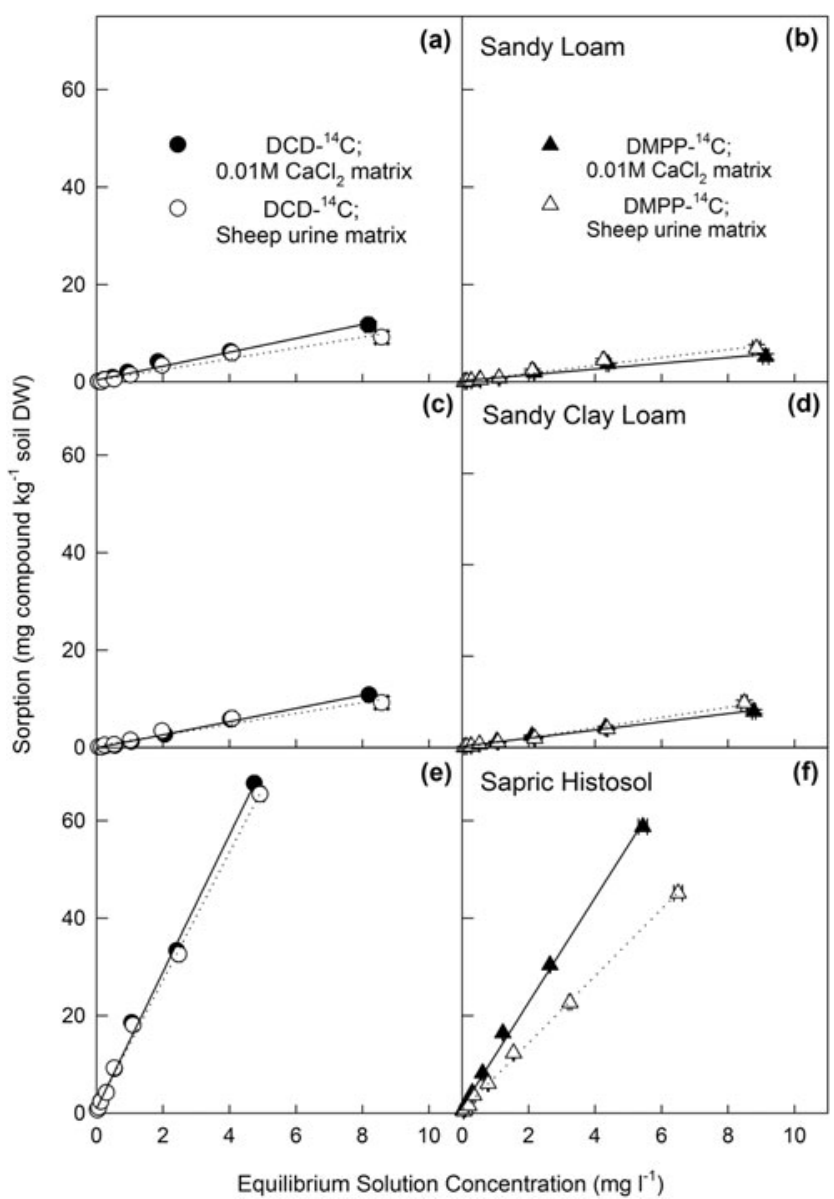

Fig. 3 Linear sorption isotherms for ${ }^{14} \mathrm{C}-\mathrm{DCD}(\mathbf{a}, \mathbf{c}, \mathbf{e})$ and ${ }^{14} \mathrm{C}$-DMPP $(\mathbf{b}, \mathbf{d}, \mathbf{f})$ in either a $0.01 \mathrm{M} \mathrm{CaCl}_{2}$ or sheep urine matrix, in a sandy loam $(\mathbf{a}, \mathbf{b})$, sandy clay loam $(\mathbf{c}, \mathbf{d})$ and Sapric Histosol $(\mathbf{e}, \mathbf{f})$. Symbols represent means $(n=3)$, bi-directional error bars represent SEM for sorption and equilibrium solution concentrations, legends apply to each column of panels and soil type labels apply to each row of panels

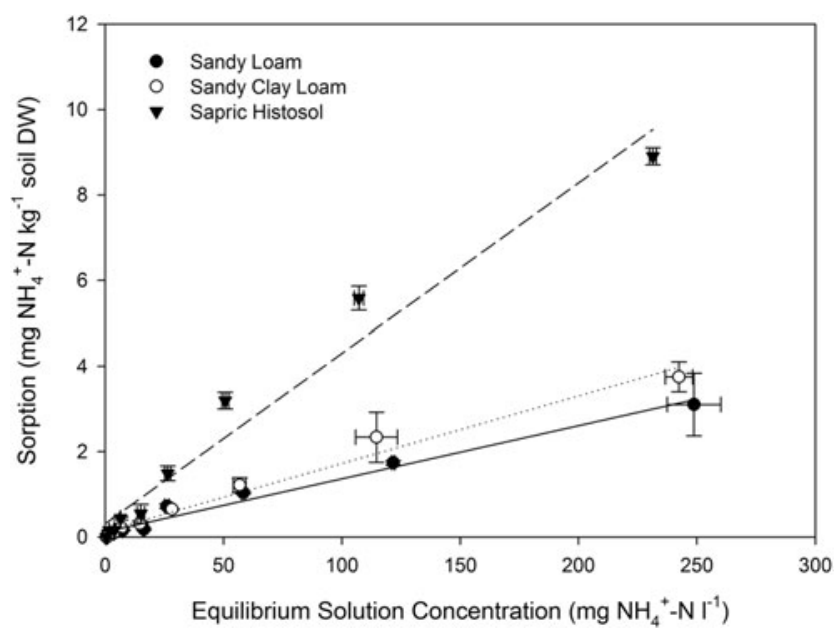

Fig. 4 Linear sorption isotherms of $\mathrm{NH}_{4}^{+}$in $0.01 \mathrm{M} \mathrm{CaCl}_{2}$ matrix, in three soils (sandy loam and sandy clay loam textured Eutric Cambisol and a Sapric Histosol). Symbols represent means $(n=3)$ and bi-directional error bars represent SEM for sorption and equilibrium solution concentrations from 0.03 to $0.16 \%$ of the added ${ }^{14} \mathrm{C}$ label. After $8 \mathrm{~h}$, the amount of ${ }^{14} \mathrm{C}-\mathrm{DCD}$ mineralized was still low, ranging from 0.41 to $1.67 \%$ of the ${ }^{14} \mathrm{C}$-label applied in the three soil types and at both studied concentrations; the amount of ${ }^{14} \mathrm{C}$-DMPP mineralized after $8 \mathrm{~h}$ ranged from 0.05 to $0.25 \%$ of the applied label. Greater amounts $(p<0.01$; $0.84 \pm 0.15$ and $1.53 \pm 0.30 \%$ more at 0.1 and $1 \mathrm{~g} \mathrm{NI}{ }^{-1}$, respectively) of ${ }^{14} \mathrm{C}$-DCD mineralized in the Sapric Histosol in comparison to ${ }^{14} \mathrm{C}$-DMPP, at both studied concentrations. The same pattern was also seen for the sandy clay loam textured Eutric Cambisol at $0.1 \mathrm{~g} \mathrm{NI} \mathrm{l}^{-1}$, where $0.83 \pm 0.12 \%$ more ${ }^{14} \mathrm{C}$-DCD was mineralized in comparison to ${ }^{14} \mathrm{C}$-DMPP. No differences were observed in the amount of ${ }^{14} \mathrm{C}$-DMPP mineralized between all soil types at either studied concentration. For ${ }^{14} \mathrm{C}-\mathrm{DCD}$ at $0.1 \mathrm{~g} \mathrm{l}^{-1}, 1.17 \pm 0.21 \%$ and $0.69 \pm 0.18 \%$ more ${ }^{14} \mathrm{C}-\mathrm{DCD}$ mineralized in the Sapric Histosol in comparison to either the sandy loam or sandy clay loam textured Eutric Cambisol, respectively. No differences $(p>0.05)$ were observed in the amount of ${ }^{14} \mathrm{C}$-DCD mineralized between the different soils at the higher studied concentration.

\section{Microbial uptake}

After $1 \mathrm{~h}$ in the sandy loam textured Eutric Cambisol, no difference $(p<0.05)$ was observed between the amount of DCD $-{ }^{14} \mathrm{C}$ or DMPP- ${ }^{14} \mathrm{C}$ acquired by the soil microbes, which ranged between 20 and $23 \%$ of that applied, at both studied concentrations. The same trend was observed in the sandy clay loam textured Eutric Cambisol, where uptake ranged from 18 to $28 \%$ of that applied. In the Sapric Histosol, greater amounts $(p<0.001)$ of DCD- ${ }^{14} \mathrm{C}(66 \pm 0.36 \%)$ was acquired by soil microbes in comparison to DMPP- ${ }^{14} \mathrm{C}(51 \pm 2.67 \%)$ at the higher application rate; however, no differences $(p>0.05)$ between DCD- ${ }^{14} \mathrm{C}(56 \pm 0.32 \%)$ and DMPP $-{ }^{14} \mathrm{C}(61$ $\pm 1.01 \%$ ) were observed at the lower concentration. The microbial uptake was two- to threefold greater $(p<0.001)$ in the Sapric Histosol compared to the mineral soils for both NI and at both studied concentrations. The results of the microbial uptake study correspond well with that of the soil column studies, indicating that the deficit in the amount of ${ }^{14} \mathrm{C}-\mathrm{NI}$ recovered from the soil columns is that which was immobilised into microbial biomass and degraded within the soils.

\section{Discussion}

Our first hypothesis was that DCD would be more mobile and translocate further down the soil profile than DMPP, due to the positive charge and rapid sorption of DMPP to soil colloids (Azam et al. 2001). The results of the column study investigating the vertical movement of DCD and 
Table 2 Soil-to-solution partition coefficient $\left(K_{\mathrm{d}}\right)$ for the nitrification inhibitors DCD and DMPP at field relevant concentrations $\left(1\right.$ and $\left.10 \mathrm{mg} 1^{-1}\right)$ with and without the presence of sheep urine

\begin{tabular}{|c|c|c|c|c|c|c|}
\hline \multirow[t]{2}{*}{ Soil type } & \multirow[t]{2}{*}{ Matrix } & \multicolumn{2}{|l|}{ DCD } & \multicolumn{2}{|l|}{ DMPP } & \multirow{2}{*}{$\begin{array}{l}\mathrm{NH}_{4}^{+} \\
300 \mathrm{mg} \mathrm{N}^{-1}\end{array}$} \\
\hline & & $1 \mathrm{mg} \mathrm{l}^{-1}$ & $10 \mathrm{mg} \mathrm{l}^{-1}$ & $1 \mathrm{mg}^{-1}$ & $10 \mathrm{mg}^{-1}$ & \\
\hline Sandy loam textured Eutric Cambisol & $0.01 \mathrm{M} \mathrm{CaCl}_{2}$ & $1.25 \pm 0.10$ & $1.34 \pm 0.05$ & $0.87 \pm 0.01$ & $0.63 \pm 0.05$ & $1.27 \pm 0.35$ \\
\hline Sandy clay loam textured Eutric Cambisol & $0.01 \mathrm{M} \mathrm{CaCl}_{2}$ & $1.88 \pm 0.05$ & $1.48 \pm 0.09$ & $1.15 \pm 0.05$ & $0.93 \pm 0.05$ & $1.56 \pm 0.18$ \\
\hline Sapric Histosol & $0.01 \mathrm{M} \mathrm{CaCl}_{2}$ & $15.6 \pm 0.28$ & $14.3 \pm 0.31$ & $12.8 \pm 0.33$ & $11.0 \pm 0.44$ & $3.86 \pm 0.11$ \\
\hline Sandy loam textured Eutric Cambisol & Sheep urine & $0.64 \pm 0.10$ & $0.64 \pm 0.18$ & $0.96 \pm 0.05$ & $0.84 \pm 0.08$ & - \\
\hline Sandy clay loam textured Eutric Cambisol & Sheep urine & $1.47 \pm 0.15$ & $1.17 \pm 0.18$ & $1.01 \pm 0.04$ & $1.11 \pm 0.07$ & - \\
\hline Sapric Histosol & Sheep urine & $15.0 \pm 0.36$ & $13.4 \pm 0.66$ & $7.73 \pm 0.43$ & $6.99 \pm 0.35$ & - \\
\hline
\end{tabular}

Values represent means $(n=3) \pm \mathrm{SEM}$

DMPP over $0-15 \mathrm{~cm}$ under a 40 -mm rainfall event revealed that the mobility of both NI were similar, and DCD did not appear to be more mobile than DMPP. A greater sorption for DCD in comparison to DMPP was found in the organic and mineral soils, contradicting our hypothesis that a greater adsorption of DMPP would occur. A greater sorption was found in the Sapric Histosol compared to the mineral soils for both NI, suggesting negatively charged domains within organic matter are important for adsorption processes. However, if the results

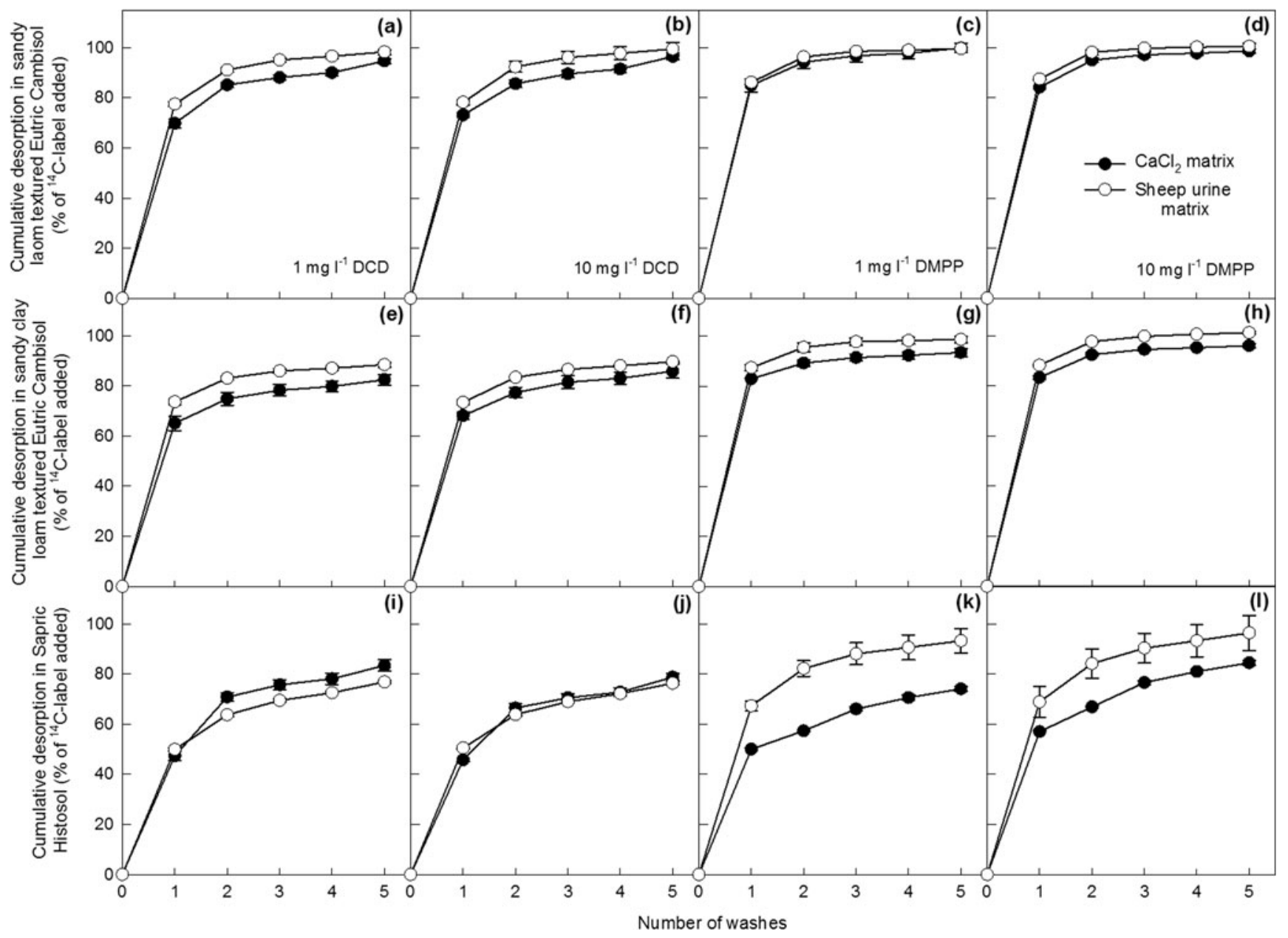

Fig. 5 Cumulative desorption of ${ }^{14} \mathrm{C}$-DCD and ${ }^{14} \mathrm{C}$-DMPP in a sandy loam (a-d), sandy clay loam $(\mathbf{e}-\mathbf{h})$ and a Sapric Histosol (i-l) at $1 \mathrm{mg} \mathrm{DCD} 1^{-1}(\mathbf{a}, \mathbf{e}, \mathbf{i}), 10 \mathrm{mg} \mathrm{DCD}{ }^{-1}(\mathbf{b}, \mathbf{f}, \mathbf{j}), 1 \mathrm{mg} \mathrm{DMPP}^{-1}(\mathbf{c}, \mathbf{g}$, k) and $10 \mathrm{mg} \mathrm{DMPP} 1^{-1}(\mathbf{d}, \mathbf{h}, \mathbf{l})$ in either a $0.01 \mathrm{M} \mathrm{CaCl}_{2}$ or sheep urine matrix. Text in the top row of panels applies to each respective column of panels and legend applies to all panels. Symbols represent means $(n=3)$ and error bars represent SEM for sorption and equilibrium solution concentrations 
of Fig. 3 are expressed on a per gram of organic C basis, the results between the soils are more similar, suggesting a partition phenomenon rather than charged-based sorption. Compounds possessing a greater octanol-water partition coefficient than others will show slower sorption; the octanol-water partition coefficient ( $\log$ P) of DCD and DMPP is predicted to be -1.03 and 0.92 for DCD and DMPP, respectively (Chemicalize.org 2016). In addition, DCD is hydrophilic (Turowski and Deshmukh 2004), which in combination with the low value for the octanol-water partition coefficient suggests strong absorption and permeation into organic matter. Protection and occlusion of NI from nitrifiers and other microbes due to sorption may reduce the effectiveness of NI, at least in the short term. Sorption may also protect against some microbial degradation, and if remobilisation of NI occurs, it may prolong the inhibitory effect (Barth et al. 2001).

Under some circumstances, DMPP has been found to be more effective than DCD at inhibiting nitrification and reducing $\mathrm{N}_{2} \mathrm{O}$ losses (Weiske et al. 2001; Chaves et al. 2006; Irigoyen et al. 2006) and this difference in efficacy is often attributed to the lower mobility of DMPP in comparison to DCD and hence a greater spatial separation of DCD with $\mathrm{NH}_{4}{ }^{+}$. Nevertheless, the inhibition of the oxidation of $\mathrm{NH}_{4}{ }^{+}$to $\mathrm{NO}_{3}{ }^{-}$only occurs when the nitrifying population have taken up the NI. This study only examined the mobility of $\mathrm{NI}$ and $\mathrm{NH}_{4}{ }^{+}$; however, a consideration of the distribution of nitrifying microorganisms and their acquisition of the NI is an important aspect for future research. Our second hypothesis was that DMPP would co-locate with urine- $\mathrm{NH}_{4}{ }^{+}$more than DCD. In our study, both NI appeared to coincide well with urine-derived $\mathrm{NH}_{4}{ }^{+}$, with only few incidences of the percentage of extractable $\mathrm{NH}_{4}{ }^{+}$being higher than the extractable NI- ${ }^{14} \mathrm{C}$ label at depth. Nevertheless, this study only focused on the short-term coincidence of NI with urine- $\mathrm{NH}_{4}{ }^{+}$, and further generation of urine- $\mathrm{NH}_{4}{ }^{+}$would occur post urea hydrolysis. Being a neutral compound, urea may also be susceptible to vertical transport (Dawar et al. 2011). However, urea hydrolysis is normally complete within ca. 2 days, reducing the time available for vertical movement. Comparing the soil-to-solution partition coefficients of the NI and $\mathrm{NH}_{4}{ }^{+}$, it appears that the $K_{\mathrm{d}}$ of $\mathrm{NH}_{4}{ }^{+}$and DCD are more similar than that of DMPP and $\mathrm{NH}_{4}{ }^{+}$in the sandy loam and the sandy clay loam soils, but large differences were found for both NI compared to $\mathrm{NH}_{4}{ }^{+}$in the Sapric Histosol. It may be possible to use NI and $\mathrm{NH}_{4}{ }^{+} K_{\mathrm{d}}$ values from differing soil types in order to assess which (if any) inhibitor may be more effective, where similar $K_{\mathrm{d}}$ values may result in a greater co-location of the two chemicals. Further work is required to assess whether this would be a useful proxy for reducing $\mathrm{N}_{2} \mathrm{O}$ emissions and improving NI use in order to maximise efficacy.
The third objective was to determine if the presence of sheep urine resulted in a greater vertical movement of both NI. Without the presence of urine (rainfall only), a retention of DCD was observed in the top $1 \mathrm{~cm}$ of the sandy loam and sandy clay loam textured soils, and a retention of both NI was found in the top $1 \mathrm{~cm}$ of the Sapric Histosol. A retention of NI at the surface may be beneficial in that nitrification decreases with pasture soil depth (Young et al. 2002), which may result in a greater coincidence of NI with nitrifiers; nevertheless, the use of sieved soils in this study would have altered any natural depth distribution of nitrifiers in the incubated soil profiles. The addition of sheep urine to the soil columns had a mixed effect on the depth distribution of the NI, depending on the soil type and inhibitor. Relative to simulated rainfall alone, the presence of sheep urine resulted in a greater amount of extractable DCD- ${ }^{14} \mathrm{C}$ at the bottom of the sandy loam soil columns and reduced the extractable amount of both DCD- ${ }^{14} \mathrm{C}$ and DMPP- ${ }^{14} \mathrm{C}$ in the top $1 \mathrm{~cm}$ of the sandy loam soil columns; however, no differences in depth distribution of either NI were observed following sheep urine and rainfall application to the sandy clay loam soil. The presence of sheep urine resulted in lower amounts of DMPP $-{ }^{14} \mathrm{C}$ at the top $1 \mathrm{~cm}$ and greater amounts of extractable DMPP- ${ }^{14} \mathrm{C}$ at $12-15 \mathrm{~cm}$ in the Sapric Histosol, but no such trend was observed for DCD- ${ }^{14} \mathrm{C}$. To consider the reasons behind these results, a consideration of the soil, NI and urine properties is required.

The soils used in this study were all of a similar $\mathrm{pH}$ (Table 1); however, the addition of urine would have altered the soil $\mathrm{pH}$ and made conditions in the soil columns more alkaline. As DCD is amphipathic, sorption has been shown to be $\mathrm{pH}$ dependent, where increases in $\mathrm{pH}$ above $\mathrm{pH} 5$ lead to increased sorption (Zhang et al. 2004). This may partially explain why the vertical distribution of $\mathrm{DCD}-{ }^{14} \mathrm{C}$ was similar whether urine was present or not in the Sapric Histosol. In the solubility assay, DMPP was found to be over 1.5 times more soluble in water than DCD. However, a saturated solution $\left(125 \mathrm{~g} \mathrm{l}^{-1}\right)$ of DMPP is acidic (ca. $\mathrm{pH} 3$ ), whereas dissolving DCD results in a near neutral $\mathrm{pH}$. The solubility of DMPP at pH 7 is reported to be $46 \mathrm{~g} \mathrm{l}^{-1}$ (Zerulla et al. 2001) - considering this value results in DCD having a greater solubility than DMPP. Thus, DMPP solubility may vary widely as a function of soil $\mathrm{pH}$ and buffer capacity, but whether this influences the mobility relative to DCD is unclear. As the soils used in this study had a similar $\mathrm{pH}$, NI solubility would not have varied much due to the effect of soil type.

The sandy loam and sandy clay loam soils had a similar CEC and organic matter content (Table 1); however, both parameters were greater in the Sapric Histosol. The NI sorption and partitioning into organic matter and the availability of cation exchange sites may have all contributed to the 
differences in the distribution of the NI, with and without the presence of urine. The low CEC in the mineral soils and saturation of these exchange sites with cations present within the urine may explain the higher amounts of DCD- ${ }^{14} \mathrm{C}$ and DMPP $-{ }^{14} \mathrm{C}$ at the bottom of the sandy loam soil columns, compared to the rainfall only treatment. This trend did not hold true, however, for the sandy clay loam columns despite the similarity in soil properties.

The results of our desorption assays revealed that even after one wash with $0.01 \mathrm{M} \mathrm{CaCl}_{2}$, a large proportion of DCD and DMPP was remobilised into solution (Fig. 5). This supports the theory that remobilisation of these NI may occur, e.g. following urine deposition and/or heavy rainfall events. In the case of ruminant urine events, this effect may be important, as urine is generally deposited at varying times following NI application to pasture. While the presence of urine generally increased desorption, the effect was strongest for DMPP- ${ }^{14} \mathrm{C}$ in the Sapric Histosol and weakest for DCD- ${ }^{14} \mathrm{C}$ in the same soil type. This again shows a clear contrast in the binding mechanisms and behaviour of these two NI. In the Sapric Histosol, the vertical movement of DMPP was enhanced due to the presence of urine. This trend was not observed for DCD, which may be due to differences in the physico-chemical properties of these NI. The partitioning and adsorption of DCD in the organic soil may have prevented its vertical movement due to urine addition.

The short-term microbial mineralization of DCD was faster in comparison to DMPP in all soil types, which supports our fourth hypothesis. This is consistent with results of other studies, where DMPP has been found to have a longer residence time in comparison to DCD (Chaves et al. 2006). DCD degrades to $\mathrm{CO}_{2}$ and $\mathrm{NH}_{4}^{+}$via guanylic urea, guanidine and urea (Amberger 1986; Kelliher et al. 2008). The first stage of DCD degradation can occur on the surface of metal oxides, which catalyse the reaction of DCD and water to guanylurea (Hallinger et al. 1990). Biological degradation of DCD by common soil microorganisms has also been demonstrated, where DCD is supplied as the sole $\mathrm{N}$ source in pure culture (Hauser and Haselwandter 1990; Schwarzer et al. 1998). As DMPP is a heterocyclic compound, it is not readily degradable (Chaves et al. 2006), although information on the mechanism and degradation pathways of this inhibitor are still lacking. Results from this study indicate that the microbial community were better able to degrade DCD in comparison to DMPP, where DMPP degrading bacteria may take longer time periods to establish in comparison to DCD. DMPP has also been found to have a longer effect on the abundance of ammonium-oxidising bacteria in comparison to DCD (Kou et al. 2015), and there is evidence that DMPP has an inhibitory effect on both ammonium-oxidising bacteria and archaea (Florio et al. 2014).
In this study, even after $1 \mathrm{~h}$, the microbial uptake of both inhibitors accounted for a large proportion of that applied. Approximately $20 \%$ was taken up by soil microbes in the mineral soils and $>50 \%$ of that applied was taken up by soil microbes in the Sapric Histosol, which was likely to be a function of the greater microbial biomass in this soil. To be effective, the NI would need to be acquired by the target microbial communities (ammonium-oxidising bacteria and archaea). Immobilisation into non-target microbial communities could, therefore, equate to a fairly large removal mechanism for these NI, and this requires further investigation. No difference was observed between DCD and DMPP in the proportion acquired by soil microbes in the mineral soils. However, uptake was greater for DCD compared to DMPP in the Sapric Histosol at the higher studied concentration. This suggests a slight preference of, or bioavailability of, DCD to the soil microbial community in the short term.

The results of this study should be considered with care, as repacked soils were used, and there were no preferential flow pathways as would occur under field conditions, which would potentially enhance the vertical movement of either NI. The soils were also sieved, which removed any natural variation of soil properties which can occur with depth. The use of soil columns could have also promoted vertical movement of NI or urine, by restricting lateral diffusion. This is in contrast to the study by Azam et al (2001), where shallow petri dishes were used and $\mathrm{NI}$ and $\mathrm{NH}_{4}{ }^{+}$were applied in the centre. This approach may have promoted lateral movement of solutes. Further work should attempt to establish the comparative efficacy of both NI, their uptake by nitrifying and non-nitrifying microorganisms and co-location with $\mathrm{NH}_{4}^{+}$over longer time scales and under field conditions.

\section{Conclusions}

A similar distribution of DCD and DMPP was observed up to a depth of $15 \mathrm{~cm}$ following a simulated rainfall event in one organic and two mineral soils. The presence of sheep urine did not influence the depth distribution of DCD following rainfall, but enhanced the movement of DMPP down the profile, especially in the organic soil. A greater sorption was found for DCD in comparison to DMPP in the soil types studied here, and the presence of urine generally increased desorption of both NI. The results of our study suggest that the efficacy of $\mathrm{NI}$ is influenced more by differences in microbial uptake and degradation rates than by differences in sorption and desorption rates to the soil matrix.

Acknowledgments KAM would like to thank the School of Environment, Natural Resources and Geography, Bangor University, for sponsoring this study. This work was supported by the UK Natural Environment Research Council, under grant award NE/M015351/1. 
Open Access This article is distributed under the terms of the Creative Commons Attribution 4.0 International License (http:// creativecommons.org/licenses/by/4.0/), which permits unrestricted use, distribution, and reproduction in any medium, provided you give appropriate credit to the original author(s) and the source, provide a link to the Creative Commons license, and indicate if changes were made.

\section{References}

Amberger A (1986) Potentials of nitrification inhibitors in modern Nfertilizer management. J Plant Nutr Soil Sc 149:469-484

Azam F, Benckiser G, Müller C, Ottow JCG (2001) Release, movement and recovery of 3,4-dimethylpyrazole phosphate (DMPP), ammonium, and nitrate from stabilized nitrogen fertilizer granules in a silty clay soil under laboratory conditions. Biol Fertil Soils 34:118-125

Ball DF (1964) Loss-on-ignition estimate of organic matter and organic carbon in calcareous soils. J Soil Sci 15:84-92

Barth G, von Tucher S, Schmidhalter U (2001) Influence of soil parameters on the effect of 3,4-dimethylpyrazole-phosphate as a nitrification inhibitor. Biol Fertil Soils 34:98-102

Barth G, von Tucher S, Schmidhalter U (2008) Effectiveness of 3,4dimethylpyrazole phosphate as nitrification inhibitor in soil as influenced by nitrification inhibitor concentration, application form, and soil matric potential. Pedosphere 18:378-385

Bateman EJ, Baggs EM (2005) Contributions of nitrification and denitrification to $\mathrm{N}_{2} \mathrm{O}$ emissions from soils at different water-filled pore space. Biol Fertil Soils 41:379-388

Benckiser G, Christ E, Herbert T, Weiske A, Blome J, Hardt M (2013) The nitrification inhibitor 3,4-dimethylpyrazole-phosphate (DMPP) - quantification and effects on soil metabolism. Plant Soil 371:257-266

Carrillo-González R, Šimůnek J, Sauve S, Adriano D (2006) Mechanisms and pathways of trace element mobility in soils. Adv Agron 91:111-178

Chaves B, Opoku A, De Neve S, Boeckx P, Van Cleemput O, Hofman G (2006) Influence of DCD and DMPP on soil N dynamics after incorporation of vegetable crop residues. Biol Fertil Soils 43:62-68

Chemicalize.org (2016). Used for name to structure generation/prediction of $\log$ P properties. January 2016, chemicalize.org and Chemaxon (http://www.chemaxon.com)

Dawar K, Zaman M, Rowarth JS, Blennerhassett J, Turnbull MH (2011) Urea hydrolysis and lateral and vertical movement in the soil: effects of urease inhibitor and irrigation. Biol Fertil Soils 47:139-146

de Klein CAM, Cameron KC, Di HJ, Rys G, Monaghan RM, Sherlock RR (2011) Repeated annual use of the nitrification inhibitor dicyandiamide (DCD) does not alter its effectiveness in reducing N2O emissions from cow urine. Anim Feed Sci Tech 166:480-491

Di HJ, Cameron KC (2003) Mitigation of nitrous oxide emissions in spray-irrigated grazed grassland by treating the soil with dicyandiamide, a nitrification inhibitor. Soil Use Manage 19: 284-290

Di HJ, Cameron KC (2004) Treating grazed pasture soil with a nitrification inhibitor eco-n $\mathrm{n}^{\mathrm{TM}}$, to decrease nitrate leaching in a deep sandy soil under spray irrigation - a lysimeter study. New Zeal J Agr Res 47:351-361

Di HJ, Cameron KC (2007) Nitrate leaching losses and pasture yields as affected by different rates of animal urine nitrogen returns and application of a nitrification inhibitor - a lysimeter study. Nutr Cycle Agroecosys 79:281-290

Di HJ, Cameron KC (2011) Inhibition of ammonium oxidation by a liquid formulation of 3,4-dimethylpyrazole phosphate (DMPP) compared with a dicyandiamide (DCD) solution in six New Zealand grazed grassland soils. J Soil Sediment 11:1032-1039

Di HJ, Cameron KC (2012) How does the application of different nitrification inhibitors affect nitrous oxide emissions and nitrate leaching from cow urine in grazed pastures. Soil Use Manage 28:54-61

Fangueiro D, Fernandes A, Coutinho J, Mreira N, Trindade H (2009) Influence of two nitrification inhibitors (DCD and DMPP) on annual ryegrass yield and soil mineral $\mathrm{N}$ dynamics after incorporation with cattle slurry. Commun Soil Sci Plan 40:3387-3398

Fiencke C, Bock E (2006) Immunocytochemical localization of membrane-bound ammonia monooxygenase in cells of ammonia oxidizing bacteria. Arch Microbiol 185:99-106

Florio A, Clark AM, Hirsch PR, Jhurreea D, Benedetti A (2014) Effects of the nitrification inhibitor 3,4-dimethylpyrazole phosphate (DMPP) on abundance and activity of ammonia oxidizers in soil. Biol Fertil Soils 50:795-807

Gilsanz C, Báez D, Misselbrook TH, Dhanoa MS, Cárdenas LM (2016) Development of emission factor and efficiency of two nitrification inhibitors, DCD and DMPP. Agri Ecosyst Environ 216:1-8

Hallinger S, Wallnöfer PR, Goldbach H, Amberger A (1990) Several aspects of bacterial dicyandiamide degradation. Naturwissenchaften 77:332-334

Hauser M, Haselwandter K (1990) Degradation of dicyandiamide by soil bacteria. Soil Biol Biochem 22:113-114

Hill PW, Kusyakov Y, Jones D, Farrar J (2007) Response of root respiration and root exudation to alterations in root $\mathrm{C}$ supply and demand in wheat. Plant Soil 291:131-141

IPCC (2007) Climate change 2007: The physical science basis. In: Solomon S, Qin D, Manning M, Chen Z, Marquis M, Averyt KB, Tignor M, Miller HL (eds) Contribution of working group I to the fourth assessment report of the intergovernmental panel on climate change. Cambridge University Press, Cambridge, p 996

Irigoyen I, Lamsfus C, Aparico-Tejo P, Muro J (2006) The influence of 3, 4-dimethylpyrazole phosphate and dicyandiamide on reducing nitrate accumulation in spinach under Mediterranean conditions. J Agr Sci 144:555-562

Jones DL, Willett VB (2006) Experimental evaluation methods to quantify dissolved organic nitrogen (DON) and dissolved organic carbon (DOC) in soil. Soil Biol Biochem 5:991-999

Kelliher FM, Clough TJ, Clark H, Rys G, Sedcole JR (2008) The temperature dependence of dicyandiamide (DCD) degradation in soils: a data synthesis. Soil Biol Biochem 40:1878-1882

Kou YP, Wei K, Chen GX, Wang ZY, Xu H (2015) Effects of 3,4dimethylpyrazole phosphate and dicyandiamide on nitrous oxide emission in a greenhouse vegetable soil. Plant Soil Environ 61:29-35

Ledgard SF, Luo J, Sprosen MS, Wyatt JB, Balvert SF, Lindsey SB (2014) Effects of the nitrification inhibitor dicyandiamide (DCD) on pasture production, nitrous oxide emissions and nitrate leaching in Waikato, New Zealand. New Zeal J Agr Res 57:294-315

Liu C, Wang K, Zheng X (2013) Effects of nitrification inhibitors (DCD and DMPP) on nitrous oxide emission, crop yield and nitrogen uptake in as wheat maize cropping system. Biogeosciences 10: 2427-2437

Luo J, Ledgard S, Wise B, Welten B, Lindsey S, Judge A, Sprose M (2015) Effects of dicyandiamide (DCD) delivery method, application rate, and season on pasture urine patch nitrous oxide emissions. Biol Fertil Soils 51:453-464

McGeough KL, Watson CJ, Müller C, Laughlin JR, Chadwick DR (2016) Evidence that the efficacy of the nitrification inhibitor dicyandiamide (DCD) is affected by soil properties in UK soils. Soil Biol Biochem 94:222-232

Miranda KM, Epsey MG, Wink DA (2001) A rapid, simple, spectrophotometric method for simultaneous detection of nitrate and nitrite. Nitric Oxide 5:62-71 
Misselbrook TH, Cardenas LM, Camp V, Thorman RE, Williams JR, Rollett AJ, Chambers BJ (2014) An assessment of nitrification inhibitors to reduce nitrous oxide emissions from UK agriculture. Environ Res Lett 9:115006

Mulvaney RL (1996) Nitrogen — inorganic forms. In: Sparks DL (ed) Methods of soil analysis. Part 3. Soil Science Society of America Inc., Madison, WI, pp 1123-1184

Murphy J, Riley JP (1962) A modified single solution method for the determination of phosphate in natural waters. Anal Chim Acta 27:31-36

O'Callaghan M, Gerard EM, Carter PE, Lardner R, Sarathchandra U, Burch G, Ghani A, Bell N (2010) Effect of the nitrification inhibitor dicyandiamide (DCD) on microbial communities in a pasture soil amended with bovine urine. Soil Biol Biochem 42:1425-1436

OECD (1995) OECD guideline for the testing of chemicals - water solubility. No. 105. OECD, Paris.

Orsonneau J-L, Massoubre C, Cabanes M, Lustenberger P (1992) Simple and sensitive determination of urea in serum and urine. Clin Chem 38:619-623

Pereira J, Fangueiro D, Chadwick DR, Misselbrook TH, Coutinho J, Trindade H (2010) Effect of cattle slurry pre-treatment by separation and addition of nitrification inhibitors on gaseous emissions and $\mathrm{N}$ dynamics: a laboratory study. Chemosphere 79:620-627

Rowell DL (1994) Soil science: methods and applications. Routledge, New York, USA

Ruser R, Schulz R (2015) The effect of nitrification inhibitors on the nitrous oxide $\left(\mathrm{N}_{2} \mathrm{O}\right)$ release from agricultural soils - a review. J Plant Nutr Soil Sc 178:171-188

Schofield RK (1949) Effect of $\mathrm{pH}$ on electric charges carried by clay particles. J Soil Sci 1:1-8

Schwarzer C, Auer B, Klima J, Haselwandter K (1998) Physiological and electron microscopical investigations on syntrophic dicyandiamide degradation by soil bacteria. Soil Biol Biochem 3:385-391

Selbie DR, Buckthought LE, Shepherd MA (2015) The challenge of the urine patch for managing nitrogen in grazed pasture systems. Adv Agron 129:229-292

Shepherd M, Wyatt J, Welten B (2012) Effect of soil type and rainfall on dicyandiamide concentrations in drainage from lysimeters. Soil Res 50:67-75

Singh J, Saggar S, Giltrap DL, Bolan NS (2008) Decomposition of dicyandiamide (DCD) in three contrasting soils, and its effects on nitrous oxide emissions, soil respiratory activity, and microbial biomass - an incubation study. Soil Res 46:517-525

Smith P, Martino D, Cai Z, Gwary D, Janzen H, Kumar P, McCarl B, Ogle S, O'Mara F, Rice C, Scholes B, Sirotenko O (2007) Agriculture. In: Metz B, Davidson OR, Bosch PR, Dave R, Meyer LA (eds) In climate change 2007: mitigation. Cambridge University Press, Cambridge, UK and New York

Turowski M, Deshmukh B (2004) Direct chromatographic method for determination of hydrogen cyanamide and dicyandiamide in aqueous solutions. Anal Lett 37:1981-1989

Voroney RP, Brookes PC, Beyaert RP (2008) Soil microbial biomass C, N, P and S. In: Carter MR, Gregorich EG (eds) Soil sampling and methods of analysis, 2nd edn. CRC Press, Boca Raton, FL, pp 637-651

Weiske A, Benckiser G, Herbert T, Ottow J (2001) Influence of the nitrification inhibitor 3,4-dimethylpyrazole phosphate (DMPP) in comparison to dicyandiamide (DCD) on nitrous oxide emissions, carbon dioxide fluxes and methane oxidation during three years of repeated application in field experiments. Biol Fertil Soils 34:109-117

Wissemeier AH, Linzmeier W, Gutser R, Weigelt W, Schmidhalter U (2001) The new nitrification inhibitor DMPP $\left(\right.$ ENTEC $\left.^{\circledR}\right)$ - comparisons with DCD in model studies and field applications. Food security and sustainability. In: Horst WJ, Schenk MK, Bürket A, Claassen N, Flessa H, Frommer WB, Golbach H, Olfs H-W, Römheld B, Sattelmacher B, Schmidhalter U, Schubert S, Wirén NV, Wittenmayer L (Eds) Plant Nutrition. Kluwer Academic Publishers, Dordrecht, the Netherlands, pp. 702-703 doi: 10.1007/ 0-306- 47624-X

Young SR, Black AS, Conyers MK (2002) Distribution of nitrification within surface soils under pasture. Commun Soil Sci Plan 33:15071518

Zerulla W, Barth T, Dressel J, Erhardt K, von Locquenghien KH, Pasda G, Rädle M, Wissemeier AH (2001) 3,4-Dimethylpyrazole phosphate (DMPP) - a new nitrification inhibitor for agriculture and horticulture. Biol Fertil Soils 34:79-84

Zhang H-J, Wu Z-J, Zhou Q-X (2004) Dicyandiamide sorptiondesorption behaviour on soils and peat humus. Pedosphere 14: 395-399 